\title{
PENDIDIKAN PERDAMAIAN KRISTEN DALAM KONTEKS INDONESIA
}

\section{Robi Prianto}

\begin{abstract}
ABSTRAK
Pendidikan formal di Indonesia dewasa ini banyak terkotakkotak oleh label suatu agama tertentu. Sehingga, di dalam pengajaran kepada para peserta didiknya lebih banyak menekankan pendidikan agama dari pada pendidikan umum. Jika masing-masing agama menerapkan pola seperti itu, maka akan terjadi sikap eksklusif dari para peserta didiknya terhadap penganut agama lain. Hal itu dapat berkembang menjadi benih-benih yang menyebabkan konflik. Oleh karena itu, dibutuhkan suatu pendidikan perdamaian yang harus terus-menerus diajarkan kepada semua peserta didik, sehingga mereka dapat mengerti dan menghargai mengenai keberagaman yang ada disekitarnya. Begitu pula dengan pendidikan perdamaian Kristen dalam konteks Indonesia, sangatlah dibutuhkan dalam kurikulum pendidikan Kristen untuk menanamkan kepada setiap peserta didik mengenai pentingnya memiliki relasi yang baik dengan Tuhan dan sesama. Banyak metode yang bisa dipakai untuk membangun sikap saling menghargai dan mengormati tersebut, salah satunya dengan cara berdialog dan gotong royong.
\end{abstract}

\section{Kata Kunci: Pendidikan, Perdamaian, Metode, Pendidikan Kristen.}

\section{PENDAHULUAN}

Sikap dan perilaku penyelesaian konflik melalui kekerasan, serta memandang kelompok yang berbeda sebagai ancaman bagi kelompok sendiri merupakan satu fenomena yang menonjol dalam masyarakat Indonesia pada pasca tumbangnya pemerintahan Orde Baru. Disamping itu, media massa (elektronik dan cetak) juga telah memertajam sisi kekerasan terhadap manusia. Anak-anak yang belum mampu bersikap kritis terhadap fenomena itu akan tumbuh dalam 
suasana yang tidak mendukung lahirnya pribadi dewasa yang memiliki komitmen nirkekerasan dalam penyelesaian konflik maupun toleransi terhadap kelompok yang berbeda. Di sisi lain, belum banyak dikembangkan bentuk alternatif pendidikan yang mendorong sikap dan perilaku damai seperti menghargai perbedaan dan kesabaran melalui diskusi untuk saling memahami kebutuhan kelompok yang berbeda dengan metode pendidikan yang memberdayakan anak.

Baru-baru ini di daerah Aceh Singkil terjadi yang namanya penutupan rumah ibadah orang Kristen (gereja) bahkan sampai ada yang dibakar oleh pihak agama lain. Sebelum peristiwa di Aceh Singkil, di Papua pun sama terjadi pelarangan oleh umat Kristen untuk melakukan ibadah bagi agama lain. Dan yang terbaru adalah pelarangan untuk mendirikan tempat ibadah (Masjid) di Manokwari oleh berbagai kalangan Kristen karena mereka menganggap Manokwari merupakan tempat pertama Injil diberitakan di Tanah Papua, sehingga mereka pun merasa memiliki hak istimewa untuk menjadikan Manokwari sebagai kota Injil, seperti daerah lainnya di Indonesia yang menerapkan syariat Islam.

Gesekan-gesekan antar penganut agama yang terjadi dibeberapa daerah di Indonesia merupakan sebuah bom waktu yang dapat meledak setiap saat, jika tidak diselesaikan dengan tuntas sampai ke akar-akarnya. Untuk menanggulangi hal tersebut maka diperlukan adanya pendidikan perdamaian bagi semua penganut agama yang ada di Indonesia, tidak terkecuali agama Kristen. Berdasarkan latar belakang masalah di atas, maka penulis tertarik untuk menulis artikel dengan judul "Pentingnya Pendidikan Perdamaian Kristen Dalam Konteks Indonesia."

Bertolak dari Pentingnya Pendidikan Perdamaian Kristen Dalam Konteks Indonesia, maka ada beberapa pertanyaan penting dalam kaitannya dengan hal tersebut. Pertama, Apakah dasar teologi pendidikan perdamaian dalam konteks Kristen? Kedua, Apakah tujuan dari pendidikan perdamaian dalam konteks Kristen? Ketiga, bagaimanakah metode pendidikan perdamaian dalam konteks Kristen? Jadi tulisan ini penting, pertama ingin menjelaskan dasar 
teologi pendidikan perdamaian dalam konteks Kristen. Kedua, ingin menjelaskan tujuan dari pendidikan perdamaian dalam konteks Kristen. Ketiga, ingin memaparkan metode pendidikan perdamaian dalam konteks Kristen.

\section{MAKNA DAN DASAR TEOLOGI PENDIDIKAN PERDAMAIAN}

\section{Pengertian Pendidikan}

Kata "pendidikan" menurut Kamus Besar Bahasa Indonesia memiliki dua arti yaitu: (1) proses sikap dan tata laku seseorang atau kelompok orang; (2) Usaha mendewasakan manusia melalui upaya pengajaran dan pelatihan; proses, cara, dan perbuatan mendidik. ${ }^{1} \mathrm{Di}$ dalam Bahasa Inggris kata "pendidikan" memakai kata education, di dalam education berarti adanya proses yang sudah berlangsung, proses yang sedang berlangsung, dan gerakan ke arah masa depan yang baru - nyata sepanjang praktik pendidikan dalam sejarah. Lawrence Cremin mendefinisikan pendidikan sebagai usaha sengaja sistematis dan terus-menerus untuk menyampaikan, menimbulkan atau memeroleh pengetahuan, sikap-sikap, nilai-nilai, keahlian-keahlian, atau kepekaan-kepekaan juga akibat dari usaha itu. Pendidikan menurut Alfred North Whitehead merupakan bimbingan bagi individu untuk memahami seni kehidupan; dan seni kehidupan adalah prestasi yang paling lengkap dari pelbagai kegiatan yang

1 Kamus Besar Bahasa Indonesia, Edisi ketiga (Jakarta: Pusat Bahasa Departemen Pendidikan Nasional, 2002), 263. 
mengekspresikan potensi-potensi makhluk hidup ketika berhadapan dengan lingkungannya yang sebenarnya. ${ }^{2}$

Jadi pendidikan merupakan suatu usaha, bimbingan yang dilakukan untuk mencapai tujuan-tujuan dalam hidup, yakni untuk memeroleh pengetahuan guna memahami, serta menjalani kehidupan.

\section{Pendidikan Kristen}

Istilah pendidikan agama (religious education) dengan akurat mendeskripsikan investigasi yang umum pada dimensi kehidupan agama dan pencarian bersama manusia terhadap dasar keberadaan yang transenden (transcendent grand of being). Pendidikan Agama Kristen merupakan istilah paling deskriptif yang dinamakan terhadap pendidikan yang dilakukan oleh komunitas Kristen dan dari dalam komunitas Kristen.

Istilah Pendidikan Agama Kristen dipakai karena istilah tersebut dapat membantu mengingatkan bahwa semua dipanggil untuk menjadi Gereja Kristen yang universal. Sama seperti semua pendidikan, Pendidikan Agama Kristen merupakan kegiatan yang kompleks, dan tidak akan pernah ada deskripsinya yang lengkap. Pendidikan Agama Kristen merupakan kegiatan politis bersama, karena memberi perhatian pada kegiatan Allah di masa kini, pada cerita komunitas iman Kristen, dan Visi Kerajaan Allah, benih-benih yang telah hadir di antara kita. ${ }^{3}$

Setiap komunitas mempunyai warisan atau kenangan yang dapat dijadikan panduan untuk hidup berkomunitas. Komunitas Kristen merupakan sebuah komunitas yang di dalamnya terdapat warisan atau sejarah pendidikan Kristen yang bisa dipakai untuk memandu pelayanan di masa kini dan masa depan. Pendidikan Kristen dan pendidikan secara umum telah bergantung pada apa yang Bernard Bailyn identifikasi sebagai sumbu utama masyarakat

2 Thomas H. Groome, Pendidikan Agama Kristen (Jakarta: BPK. Gunung Mulia, 2011), 29-30.

3 Ibid, 34-37. 
dalam studinya mengenai pendidikan di koloni Amerika Utara: keluarga, gereja, komunitas, dan ekonomi. Dalam konteks masyarakat kontemporer, pendidikan juga bergantung pada sekolah, media dan berbagai agen dan kelompok sosial serta komunitas. Sebagaimana institusi atau agen sosial ini telah berubah dari generasi ke generasi di dalam dampak relatif mereka terhadap manusia, bentuk pendidikan juga ikut berubah. Keluarga dan gereja adalah agen pendidikan yang dominan dalam kehidupan seseorang manusia. ${ }^{4}$

\section{Pendidikan Perdamaian dalam Kristen}

Kata perdamaian berasal dari akar kata damai yang memiliki arti tenteram, tenang, keadaan tidak bermusuhan. Jadi kata perdamaian berarti penghentian permusuhan (perselisihan) dan perihal damai (berdamai). ${ }^{5}$ Pendidikan perdamaian dalam konteks Kristen bukanlah merupakan suatu hal yang baru, karena ketika Tuhan Yesus memulai pelayanan-Nya di dunia ini, Dia sudah mengajarkan perdamaian kepada setiap murid-murid-Nya. Bahkan Tuhan Yesus sendiri menekankan pentingnya berdamai dengan Allah dan sesama. Di mana ketika seseorang mengasihi Allah, maka orang tersebut haruslah juga mengaplikasikan kasihnya itu kepada sesamanya manusia. Sebab seseorang tidak mungkin di satu sisi mengasihi Allah, dan di sisi yang lain membenci sesamanya manusia, dan begitupun sebaliknya. Yang benar adalah hubungan dengan Allah (vertikal) dan manusia (horizontal) harus seimbang, karena orang Kristen diajarkan untuk selalu mengasihi Allah dan sesamanya manusia (Matius 22:37-40), serta menjadi agen-agen pembawa damai dan berkat bagi orang lain.

${ }^{4}$ Robert W Pazmiño, Fondasi Pendidikan Kristen: Sebuah pengantar dalam perspektif Injili (Jakarta:BPK. Gunung Mulia, 2011), 184.

${ }^{5}$ Kamus Besar Bahasa Indonesia, Edisi ketiga, 233. 
Pendidikan perdamaian haruslah terus diajarkan kepada setiap orang Kristen dari generasi ke generasi yang dimulai dari sejak dini. Lembaga pendidikan baik formal maupun non formal memiliki peranan penting dalam mengajarkan pendidikan perdamaian, karena lembaga pendidikan semestinya harus menjadi sarana dalam mengajarkan dan membangun toleransi serta kebersamaan bukan mengajarkan mengenai eklusivisme agama. Lembaga pendidikan juga semestinya mengajarkan kepada para peserta didiknya bagaimana caranya menghargai orang lain yang berbeda dengan mereka atau dengan kata lain bagaimana caranya memanusiakan manusia.

Pendidikan perdamaian di Indonesia dapat terlaksana, apabila semua kalangan ikut terlibat di dalamnya, tidak terkecuali para pemimpin agama dan pemimpin bangsa. Sebab seharusnya para pemimpin bangsa dan agama menjadi agen-agen pembawa damai, dan bukannya menjadi provokator. Jika hal itu terjadi maka akan tercipta yang namanya perdamaian, sehingga insiden-insiden konflik yang muncul di beberapa tempat di Indonesia, tidak akan terulang kembali. Terlebih lagi bagi orang Kristen, karena Tuhan Yesus tidak pernah mengajarkan kebencian, tetapi sebaliknya Tuhan Yesus mengajarkan kasih dan cinta damai kepada setiap umat-Nya. Bahkan Tuhan Yesus mengajarkan untuk tidak membalas orang yang berbuat pada kita (Matius 5:39; Lukas 6:29).

\section{Dasar Teologi}

Gereja Purba bukanlah penemu pendidikan agama Kristen. Orang-orang Kristen pertama dibesarkan dalam negeri yang telah dipengaruhi Kebudayaan Yunani kurang lebih 200 tahun lamanya. Pendidikan agama Kristen yang dikembangkan oleh Gereja Purba merupakan usaha untuk bergumul dengan kebudayaan yang nilainilainya bertentangan terhadap lingkungan luas disekitarnya. Di dalam Gereja Purba Ada 3 macam arus yang mengalir menjadi sungai iman Kristen, yaitu Yahudi yang membawa dasar agamawi, Yunani yang membawa bahasanya, dan Romawi yang menentukan struktur ketertiban umum dan hak sipil.

Dalam sejarah umat Israel inti dari berita Perjanjian Lama telah dikaburkan dengan muncul dan berkembangnya agama Yahudi pada 
periode sesudah pembuangan ke Babel yang menekankan segi lahiriah dalam ibadah mereka. Di mana Taurat ditafsirkan dan peraturan-peraturan yang sangat memberatkan ditambahkan. Para pemimpin agama Yahudi sudah melupakan hakikat Taurat yang sebenarnya adalah menyadarkan dosa dan mencari takhta anugerah Allah. ${ }^{6}$

Dasar teologi orang Yahudi mengenai pendidikan agama telah mengalami perubahan pasca pembuangan dari Babel. Jika sebelumnya dasar teologi mereka adalah sebagai umat pilihan Allah, tetapi setelah kembali dari pembuangan dasar teologi mereka berubah, yaitu ditambahkan dengan kesadaran akan hukuman yang semestinya dijatuhkan Allah atas mereka akibat dari pelanggaran mereka terhadap hukum taurat. Atas kesadaran itu mereka kemudian memerketat pelaksanaan hukum taurat. Selain itu dasar teologi mengenai penyataan Allah juga mengalami perubahan. Di zaman sebelumnya penyataan Allah diterima secara lisan namun pada zaman ini dibuat dalam bentuk tertulis dan harus dihafal.

Alkitab adalah sumber esensial untuk mengerti keunikan Kristen dalam pendidikan. Oleh karena itu, seluruh pemikiran dan praktik para pendidik harus dipimpin oleh kebenaran penyataan Allah ketika mereka berusaha taat kepada Kristus dalam menjalankan tugasnya sebagai pendidik. Mereka biasanya mengalami kebingungan dalam menghadapi keragaman teori pendidikan dalam masyarakat kontemporer. Dalam situasi seperti tersebut, eksplorasi terhadap fondasi alkitabiah menjadi penting untuk menilai praktik pendidikan. Penyelidikan seperti ini tidak menghasilkan teori dan praktik pendidikan yang steril atau kaku, yang tanpa ruang bagi kreativitas. Sebaliknya, pendidikan Kristen yang dibangun di atas pola berdasar

${ }^{6}$ Paulus L.Kristianto, Prinsip dan Praktik PAK (Yogyakarta: Andi, 2006), 11. 
Alkitab justru memberi pengalaman edukasional yang dinamis dan beragam.

Robert W Pazmino berpandangan untuk dapat memahami pendidikan Kristen dan praktik pendidikan secara bertanggung jawab dari sudut pandang teologi Injili, para pendidik Kristen, harus berhati-hati memeriksa fondasi alkitabiah yang mendasari praktik pendidikan Kristen. Ada beberapa fondasi alkitabiah dalam Alkitab Perjanjian Lama dan Perjanjian Baru. Fondasi-fondasi tersebut menawarkan berbagai model atau paradigma ketika membaca teks Alkitab. Semua pendidik mempunyai paradigma tersendiri yang mengarahkan pemikiran dan praktik pendidikan mereka.

Perjanjian Lama memberi variasi yang luas tentang konteks historis dan komunal untuk mengeksplorasi hakikat dari belajar mengajar dalam komunitas orang Israel. Pazmino mengikuti pemikiran Matias Preiswerk yang mengidentifiaksi berbagai agen pendidikan, yang terdiri dari para nabi, imam, dan orang Lewi, orang bijak, ahli Taurat, termasuk juga umat Israel sebagai suatu bangsa. Setiap agen pendidik ini mempunyai tujuan, konten, metode dan ekspresi institusional tersendiri.

Kitab Ulangan menekankan pentingnya meneruskan konten dan norma-norma yang mendasar bagi kehidupan dari komunitas iman dari bangsa Israel. Walter Brueggemann mengidentifikasi komponen kanon Perjanjian Lama tersebut sebagai etos dari Taurat, yang perlu disingkapkan karena itulah yang menjadi pengikat dari suatu komunitas iman.

Dalam Taurat, Kitab Ulangan merupakan kitab yang utama dalam hal menggariskan norma-norma yang harus ditaati oleh komunitas iman dan diajarkan kepada generasi berikutnya. Bisa dikatakan bahwa titik pijak pendidikan agama pada era Israel, dan kemudian berkembang pada masa-masa sesudahnya, adalah Ulangan 6, utamanya ayat 1-2, 4-9.

Mandat pendidikan di dalam Ulangan 6:4-9 berisi mengenai kewajiban untuk menyampaikan perintah-perintah Allah kepada generasi selanjutnya. Tujuan akhirnya adalah menanamkan kasih akan Allah yang diekspresikan lewat kesetiaan dan ketaatan. 
Mengasihi Allah identik dengan menjawab pangilan yang unik (Ulangan 6:4), bersikap taat (Ulangan 11:1-22; 30:20), melakukan hukum Allah (Ulangan 10:12; 11:1, 22; 19:9), mengindahkan dan mendengar suara Allah (Ulangan 11:13; 30:16), dan melayani (Ulangan 10:12; 11:1, 13). Dalam pengertian yang paling hakiki, Allah adalah pendidik di dalam pendidikan yang alkitabiah.

Konten pendidikan alkitabiah dalam Ulangan 6 yang bersifat esensial terdiri dari perintah, ketetapan, dan hukum Allah yang diperintahkan kepada Musa untuk diajarkan. Isi pengajaran bersifat mendasar dan radikal. Mendasar artinya menyediakan kebenaran yang mendasar dan menyediakan struktur untuk membangun semua aspek kehidupan. Sedangkan radikal berarti menyediakan akar bagi pertumbuhan seluruh kehidupan. Oleh karena itu, stabilitas dan pertumbuhan dapat terjadi sejauh isi pengajarannya didasarkan pada penyataan Allah.

Perjanjian Baru, sama seperti Kitab Suci orang Ibrani atau Perjanjian Lama, juga memberikan berbagai ide penting berkaitan dengan tugas mengajarkan iman. Kitab-kitab Injil dan Surat-surat Kiriman berisi suatu agenda bagi penyebarluasan iman Kristen dalam konteks yang asing atau bermusuhan. Yesus sebagai pendidik harus menerima sikap-sikap yang tidak menerima pesan yang dibawa-Nya. Fakta-fakta mengenai inkarnasi-Nya, ancaman akan dibunuh di Betlehem, penolakan atas diri-Nya di Nazaret, dan penyaliban-Nya di Yerusalem, semuanya merujuk pada risiko dan harga yang harus dibayar saat mengajarkan kebenaran di zaman-Nya.

Dalam Perjanjian Baru, pola pendidikan Perjanjian Lama tetap dipertahankan, tetapi para pengikut Yesus diberikan agenda baru

7 Pazmiño, Fondasi Pendidikan Kristen: Sebuah pengantar dalam perspektif Injïli, 15-20. 
untuk melaksanakan praktik pendidikan mereka. Agenda tersebut terlihat dengan jelas dalam Matius 28:16-20. Tujuan pelayanan pemuridan itu adalah memampukan orang lain menjadi murid-murid Yesus Kristus yang taat. Pola pengajaran dalam Injil Matius merupakan gambaran bagaimana pengajaran dilaksanakan dalam Gereja perdana. Injil Matius adalah manual pengajaran mengenai bagaimana memuridkan orang Kristen. Pengajaran Yesus dibagi menjadi lima bagian utama (Matius 5:1-7:27; 10:1-42; 13:1-52; 18:135; 23:1-25:46) yang berfungsi sebagai panduan kurikulum bagi Gerja Kristen yang baru terbentuk. Kelima bagian itu membahas area-area penting dalam kehidupan seorang Kristen. Kelima bagian tersebut bisa dikategorikan ke dalam tiga elemen yang dibagikan oleh sebuah komunitas Kristen kepada para anggotanya, yaitu visi, misi dan memori. Sebuah perikop lain yang sangat penting dalam membahas pendidikan, khususnya ketika membahas mengenai metode pengajaran adalah Lukas 24:13-35, di mana Yesus sedang berbicara dengan dua orang murid dalam perjalanan ke Emaus.

\section{Tujuan Pendidikan Perdamaian Kristen}

\section{Tujuan Umum}

Tujuan umum yang ingin dicapai di dalam pendidikan Kristen adalah adanya pendewasaan iman Kristen dari naradidik. Proses pendewasaan Kristen dapat digambarkan sesuai dengan 2 Petrus 1:38, yang menyatakan kuasa ilahi Allah telah menganugerahkan kepada setiap orang Kristen segala sesuatu yang berguna untuk hidup dan kesalehan. Segala sesuatu telah dianugerahkan, dan bagian orang Kristen hanya untuk menerimanya. Caranya melalui pengetahuan yang benar akan siapa diri-Nya. Bukan hanya fakta-fakta, tetapi pengetahuan yang penuh, pribadi, intim dan berdasarkan pengalaman. ${ }^{8}$

Berdasarkan fondasi-fondasi alkitabiah yang diterapkan dalam pendidikan Kristen, terbukalah kemungkinan untuk menyarankan

${ }^{8}$ Lois E. LeBar, Education That Is Christian (Malang: Gandum Mas, 2006), 194. 
suatu model yang mengarahkan pemikiran dan praktik pendidikan masa kini. Dr. E.V. Hill yang menggambarkan jaringan pendidikan yang dilakukan oleh Gerja merupakan hasil perpaduaan antara ajaran Yesus menurut penulis Injil dan pesan-pesan dalam surat-surat para rasUlangan Gambaran jaringan lapangan baseball Hill, dalam permainan softball memiliki aturan yang ketat, namun pemain masih bisa berlari atau keluar dari garis-gari itu. Para pendidik Kristen dapat bergerak dengan bebas dalam rangka mencapai tujuan pendidikan.

Dalam model ini, salah satu basis menggambarkan pendidikan untuk pemberitaan (kerygma), yang bertujuan membuat orang memertimbangkan komitmen pribadi mereka kepada Yesus Kristus. Tugas pemberitaan ini mencakup pengajaran dan khotbah mengenai Injil yang dilakukan bersamaan dengan pelayanan penginjilan. Iman dipandang sebagai sesuatu yang mengandung beberapa dimensi, yaitu notitia (afirmasi intelektual), assensus (afirmasi efektif), dan fiducia (afirmasi intensional) ketika seseorang merespons pekerjaan dan penyataan Allah dalam Yesus Kristus. Pendidikan dalam hal pemberitaan atau penginjilan berfokus pada memampukan seseorang untuk mengeksplorasi dan memahami dimensi-dimensi iman tersebut serta meneguhkan respons mereka. Respons seperti itu mencakup, awalnya secara pribadi, kemudian dibagikan kepada orang lain. Pemberitaan (kerygma) adalah sesuatu yang krusial dalam proses ini (Roma 10:17), dengan adanya pertemuan-pertemuan yang mengandung unsur pendidikan menjadi sarana untuk mendiskusikan isu-isu iman yang melengkapi pemberitaan Injil. ${ }^{9}$

\section{Tujuan Khusus}

Tujuan utama bagi orang Kristen bukanlah penginjilan, keserupaan dengan Kristus secara pribadi atau bahkan membangun

9 Pazmino, Fondasi Pendidikan Kristen: Sebuah Pengantar dalam Perspektif Injili, 55-57. 
gereja, tetapi menyembah Allah. Hukum yang paling utama adalah supaya setiap orang Kristen mengasihi Tuhan dengan segenap hati, jiwa, pikiran dan kekuatan (Mrk. 12:30). Memang pertumbuhan pribadi dan pembangunan gereja merupakan tugas-tugas yang penting, namun itu semua bukanlah tujuan yang utama. Melainkan semuanya itu hanyalah sarana untuk mencapai tujuan akhir dan menjadi pengukur untuk menilai sasaran-sasaran, metode-metode dan program-program pendidikan secara terus-menerus. ${ }^{10}$

Pendidikan Kristen merupakan upaya ilahi dan manusiawi yang dilakukan secara sistematis dan berkesinambungan, untuk mentransmisikan pengetahuan, nilai-nilai, sikap-sikap dan keterampilan-keterampilan serta tingkah laku yang konsisten dengan iman Kristen. Pendidikan mengupayakan perubahan, pembaruan dan reformasi pribadi-pribadi, kelompok serta struktur, oleh kuasa Roh Kudus, sehingga peserta didik hidup sesuai dengan kehendak Allah, sebagaimana dinyatakan oleh Alkitab dan oleh Tuhan Yesus sendiri. Penyelenggaraan pendidikan Kristen haruslah menolong peserta didik untuk memahami dan menaati rancangan Allah, tujuan Allah menciptakan hidup mereka. Ada komitmen yang serius untuk penyelenggaraan pendidikan Kristen yaitu memikirkan dengan benar dan mendalam, bagaimana membangun kehidupan peserta didik di atas firman Allah. Inilah yang dimaksudkan dengan karakteristik pendidikan Kristen. Dengan tegas dapat dikatakan, bila penyelenggaraan pendidikan Kristen tidak sesuai dengan karakteristik ini, berarti bukanlah pendidikan Kristen.

Misi pendidikan Kristen Berdasarkan Alkitab, terdapat di dalam Ulangan 6:6-9. Tuhan memberikan kepada setiap pendidik Kristen misi utama penyelenggaraan pendidikan Kristen. Pertama, agar setiap peserta didik menjadi seseorang yang mengenal Allah yang benar di dalam Yesus Kristus secara pribadi. Kedua, menjadi murid Kristus yang berkomitmen bahwa Tuhan berdaulat penuh atas hidup pribadinya meliputi semua aspek. Ketiga, menjadi hamba Kristus yang selalu berjalan dalam pimpinan Roh Kudus, setia menaati kehendak Tuhan sesuai ajaran Alkitab yang berotoritas 
penuh dalam hidupnya. Keempat, menjadi milik kesayangan Tuhan yang seumur hidup hanya memikirkan hal yang kudus, berkenan dan memuliakan Tuhan. ${ }^{11}$

Karena itu, sebagai hamba Tuhan dan pendidik Kristen seharusnya berkomitmen menolong setiap peserta didik agar dapat menjalani proses pembelajaran yang sesuai dengan prinsip Alkitab dan kehendak Tuhan Yesus Kristus. Sebab pendidikan Kristen mempunyai satu tujuan yang jelas dan pasti, yaitu mengenal, mengasihi, mengimani, menaati dan melayani Allah sesuai kehendak dan rencana-Nya dan untuk kemuliaan-Nya.

Jadi, penyelenggaraan Pendidikan Kristen haruslah bertujuan untuk menolong manusia membangun kehidupannya di atas dasar yang teguh yakni Alkitab, firman Allah. Inilah yang menjadi misi pendidikan Kristen.

\section{Tujuan Pendidikan Perdamaian}

Berbicara mengenai pendidikan agama Kristen di Indonesia memang tidak sama dengan pendidikan agama Kristen di negaranegara lain. Di Barat pendidikan agama Kristen diberikan di luar sekolah. Sedangkan di Indonesia pendidikan agama Kristen diberikan di sekolah mulai dari Sekolah Dasar (SD), Sekolah Menengah Pertama (SMP), Sekolah Menengah Atas (SMA/MA/SMK), bahkan sampai di Perpendidikan Tinggi (PT).

Pendidikan agama Kristen di Indonesia diatur di dalam Undang-undang No. 20 Tahun 2013 tentang Sistem Pendidikan Nasional. Berbicara mengenai pendidikan agama Kristen di Indonesia tentu tidak bisa lepas dari yang namanya standar pendidikan nasional yaitu kriteria minimal tentang sistem pendidikan

11 Samuel Sidjabat, Strategi Pendidikan Kristen (Yogyakarta: Andi, 1994), 106. 
di seluruh wilayah hukum Negara Kesatuan Republik Indonesia. ${ }^{12}$ Pendidikan keagamaan di Indonesia diatur dalam Undang-undang No. 20 Tahun 2013 tentang Sistem Pendidikan Nasional pada bagian 9 Pasal $30 .^{13}$

Negara Indonesia terdiri dari berbagai macam suku, bahasa, dan agama yang membawa pengaruh bagi sejumlah agama dunia. Pancasila sebagai dasar Negara Indonesia menunjukkan akan adanya kebebasan beragama di Indonesia. Pluralisme agama di negeri ini adalah relitas empiris yang tidak bisa dipungkiri. Pluralisme dapat dikatakan sebagi salah satu ciri khas masyarakat modern dan kelompok sosial yang paling penting dan mungkin merupakan pengemudi utama dalam kemajuan ilmu pengetahuan, masyarakat dan ekonomi.

Oleh karena latar belakang tersebut, maka tujuan pendidikan harus selalu diformulasikan dengan memerhatikan konteks budaya, keagamaan dan hal-hal lain yang berhubungan langsung ataupun tidak langsung kepada manusia dimana manusia itu berada. Namun demikian, beberapa tokoh pendidikan telah mencoba merumuskan tujuan-tujun pendidikan. Menurut Ki Hadjar Dewantara, bahwa pendidikan diselenggarakan dengan tujuan membantu peserta didik menjadi manusia yang merdeka dan mandiri, serta mampu memberi konstribusi kepada masyarakatnya. Menjadi manusia merdeka itu berarti: (a) tidak hidup terperintah; (b) berdiri tegak karena kekuatan sendiri; dan (c) cakap mengatur hidupnya dengan tertib. Singkatnya, pendidikan menjadikan orang mudah diatur tetapi tidak dapat disetir. $^{14}$

Hamka berpandangan tujuan pendidikan memiliki dua dimensi; bahagia di dunia dan di akhirat. Untuk mencapai tujuan tersebut manusia harus menjalankan tugasnya dengan baik yaitu

${ }^{12}$ Undang-undang No.20 Tahun 2003 Tentang Sistem Pendidikan Nasional (Jakarta: Kementerian Pendidikan Nasional), 3.

13 Ibid, 11-12.

14 Y. Suyitno, Tokoh-tokoh Pendidikan Dunia (Depok: Universitas Pendidikan Indonesia, 2009), 14. 
beribadah. Oleh karena itu segala proses pendidikan pada akhirnya bertujuan agar dapat menuju dan menjadikan anak didik sebagai abdi Allah yang baik. ${ }^{15}$ Jean Piaget menyebutkan bahwa tujuan pendidikan yang utama adalah untuk menciptakan orang-orang yang mampu melakukan hal-hal baru, tidak hanya mengulangi apa yang generasigenerasi lain telah lakukan - orang-orang yang kreatif, inventif, dan penemu-penemu. Tujuan pendidikan yang kedua adalah membentuk pikiran-pikiran yang kritis, dapat membuktikan, dan tidak menerima semua yang ditawarkan. ${ }^{16}$

\section{Metode Pendidikan Perdamaian Kristen Dalam Konteks Indonesia}

\section{Dialogis}

Daniel L. Migliore berpendapat bahwa ketika orang Kristen dan orang-orang dari agama lain harus menghormati iman masingmasing dengan serius, maka mereka pun harus mau membuka diri terhadap agama lainnya dengan cara membuka diri melalui dialog. Seperti yang Yesus ajarkan kepada murid-murid-Nya maupun orang banyak, di mana Yesus mengajukan pertanyaan yang baru sebagai tanggapan atas pertanyaan yang sebelumnya diajukan kepada-Nya. Pada setiap tahap pertukaran pikiran, orang yang diajak berdialog diarahkan untuk menggali pemahamannya lebih dalam lagi. ${ }^{17}$

Lebih lanjut Hans Küng mengatakan bahwa semua agama memuat campuran antara kebenaran dan kepalsuan. Oleh karena itu,

15 Ibid, 3.

${ }^{16}$ Groome, Pendidikan Agama Kristen (Jakarta: BPK. Gunung Mulia, 2010), 367.

17 Robert R, Boehlke, Sejarah Perkembangan Pikiran dan Praktik Pendidikan Agama Kristen, Dari Plato sampai IG. Loyola (Jakarta: BPK. Gunung Mulia, 2005), 65-70. 
kekristenan bisa berperan sebagai katalisator kritis, membantu agama-agama lain untuk mengeluarkan apa yang terdalam dan terbaik dalam diri mereka sambil ditantang dan diklarifikasi dalam proses spesifikasi dan kesempurnaan wahyu Kristus. ${ }^{18}$

Dalam kaitannya dengan masyarakat Indonesia yang merupakan masyarakat majemuk (suku, agama, dan bahasa), maka masyarakat Indonesia tidak mempunyai pilihan selain berdialog satu sama lain, untuk menghindari terjadinya konflik. Konflik muncul di tengah-tengah masyarakat, tetapi hal tersebut biasanya terjadi ketika satu kelompok mengklaim sesuatu hanya untuk dirinya sendiri. Menjadi masyarakat Kristen Indonesia secara alami dituntut untuk berdialog dengan orang-orang dari kepercayaan lainnya. Istilah dialog dipakai sebagai metafora inklusif bagi hubungan antar-agama yang positif di antara masyarakat yang berbeda tradisi imannya, yang sudah menjadi praktik aktual di antara kelompok masyarakat yang berbeda. $^{19}$

Semua agama yang ada di Indonesia haruslah dapat duduk bersama-sama untuk berdialog mengenai apa yang harus dilakukan bersama. Namun, di dalam berdialog antar-agama setiap perdebatan yang bersifat dogmatis yang cenderung menimbulkan konflik dan memerluas jarak haruslah dihindari. Nilai-nilai sosial yang sifatnya diperlukan dan dapat diterima oleh semua agama perlu dibangun secara bersama-sama. Dalam konteks masyarakat Indonesia, tokoh dan para pemimipin agama haruslah memberi contoh serta teladan bagi masyarakat mengenai pentingnya saling menerima perbedaan. Perlunya membangun tingkat kedewasaan emosional bagi setiap golongan, karena membangun kebersamaan dalam perbedaan bukanlah hal yang mudah, namun bukan yang mustahil untuk dilakukan, asalkan semua pihak mau berusaha.

18 Hope S. Antone, Pendidikan Kristiani Kontekstual: memertimbangkan realitas kemajemukan dalam pendidikan agama (Jakarta: BPK. Gunung Mulia, 2010), 45-46.

${ }^{19} \mathrm{Ibid}, 92-93$. 


\section{Toleransi}

Toleransi merupakan sikap penerimaan terhadap perbedaan, baik itu bahasa, suku dan termasuk juga agama. Toleransi memerlukan dialog untuk mengkomunasikan dan menjelaskan perbedaan, menuntut keterbukaan, dan menerima perbedaan tersebut sebagai realitas hidup. Perbedaan tidaklah diciptakan sendiri, melainkan sudah terbentuk dalam diri seseorang sejak dirinya lahir. Sikap toleransi akan muncul dengan sendirinya ketika para peserta didik sudah menyadari mengenai keberagaman yang ada disekitar mereka. Sistem pendidikan di Indonesia dalam beberapa dekade ini selalu menitikberatkan pada pendidikan karakter dan keberagaman pada nara untuk menghargai nilai-nilai pancasila sebagai lambang pemersatu bangsa ini.

Pendidikan perdamaian harus dimulai dari keluarga, sekolah, gereja, dan meluas ke masyarakat umum. Contoh penerapan pendidikan perdamaian dalam keluarga adalah mengajarkan anak dalam menyelesaikan suatu masalah dengan cara berdiskusi dan menyatakan pendapat secara masing-masing dan diakhiri dengan mencari solusi bersama atas masalah yang sedang dihadapi, dan bukan dengan sikap yang otoriter. Dari hal tersebut anak diajak untuk memahami nilai-nilai yang berbeda dari setiap individu dan memberikan pengertian kepada anak tersebut supaya dia bisa menerima perbedaan yang terdapat pada orang lain.

Contoh penerapan pendidikan perdamaian di sekolah adalah nara didik diajak untuk melihat nilai budaya dan agama yang berbeda dengan dirinya sehingga nara didik mengerti dan bisa menghargai orang yang berbeda budaya dan agama dengan dirinya. Kelas di dekorasi dengan nuansa budaya yang beranekaragam sehingga nara didik yang berbeda budaya tidak merasa di tolak.

Selain itu, nara didik pun harus diajar untuk saling memercayai antara satu dengan yang lainnya. Sehingga mereka dapat tumbuh menjadi generasi pembawa damai yang mengesampingkan perbedaan 
dan lebih mengutamakan kebersamaan dalam keberagaman. Sebab membangun saling percaya merupakan modal penting dalam membangun suatu bangsa yang besar seperti Indonesia, karena bangsa Indonesia terdiri dari masyarakat yang heterogen dalam banyak aspek. Pembangunan hidup masyarakat suatu bangsa yang heterogen tidak akan terjadi tanpa adanya saling percaya diantara kelompok-kelompok masyarakat yang berbeda. Perbedaan yang tidak ditangani dengan benar akan berpotensi menjadi pemicu konflik yang mengakibatkan kehancuran suatu bangsa. Oleh karena itu semenjak dini perlu ditanamkan sikap saling memercayai satu sama lain terutama di dalam lingkungan sekolah yang harus menjadi zona netral dari setiap perbedaan yang ada. Saling percaya merupakan pondasi bagi terbangunnya sikap rasional, tidak mudah curiga, dan bebas dari pra sangka buruk. Pendidikan agama haruslah menjadi pondasi utama untuk membangun saling percaya terus menerus dalam masyarakat Indonesia.

\section{Gotong Royong}

Gotong royong merupakan istilah asli Indonesia. Gotong royong merupakan suatu kegiatan yang dilakukan secara bersamasama dan bersifat suka rela agar kegiatan yang dikerjakan dapat berjalan dengan lancar, mudah dan ringan. Gotong royong sudah menjadi budaya di dalam kehidupan masyarakat Indonesia, baik itu masyarakat perkotaan maupun pedesaan. Adapun budaya gotong royong dilandasi oleh alasan yaitu manusia terikat dengan lingkungan sosialnya, pada dasarnya manusia sebagai makhluk sosial, manusia perlu menjaga hubungan baik dan selaras dengan sesamanya, manusia perlu menyesuaikan dirinya dengan anggota masyarakat lainnya.

Pola hidup bersama yang saling meringankan beban masingmasing pekerjaan merupakan strategi dari gotong royong. Adanya kerjasama semacam ini merupakan suatu bukti adanya keselarasan hidup antar sesama bagi komunitas, terutama yang masih menghormati dan menjalankan nilai-nilai kehidupan. Gotong royong sebagai bentuk solidaritas sosial, terbentuk karena adanya bantuan dari pihak lain, untuk kepentingan pribadi ataupun kepentingan 
kelompok, sehingga di dalamnya terdapat sikap loyal dari setiap warga sebagai satu kesatuan.

Namun gotong royong yang dilakukan oleh masyarakat perkotaan dengan masyarakat pedesaan memiliki nilai perbedaan, karena di perkotaan segala sesuatu sudah banyak dipengaruhi oleh materi dan sistem upah, sehingga akan diperhitungkan untungruginya dalam melakukan gotong-royong, sedangkan di pedesaan gotong-royong belum banyak dipengaruhi oleh materi dan sistem upah sehingga kegiatan gotong-royong diperlukan sebagai suatu solidaritas antar sesama dalam satu kesatuan wilayah atau kekerabatan.

Gotong-royong dapat dikatakan sebagai ciri dari bangsa Indonesia terutama mereka yang tinggal di pedesaan yang berlaku secara turun temurun, sehingga membentuk perilaku sosial yang nyata kemudian membentuk tata nilai kehidupan sosial. Adanya nilai tersebut menyebabkan gotong-royong selalu terbina dalam kehidupan komunitas sebagai suatu warisan budaya yang patut dilestarikan. Hubungannya gotong-royong sebagai nilai budaya. Adanya sistem nilai membuat gotong-royong senantiasa dipertahankan dan diperlukan dalam berbagai aspek kehidupan, sehingga gotong-royong akan selalu ada dalam berbagai bentuk yang disesuaikan dengan kondisi budaya komunitas yang bersangkutan berada. $^{20}$

Gotong-royong sebagai bentuk integrasi, banyak dipengaruhi oleh rasa kebersamaan antar warga komunitas yang dilakukan secara sukarela tanpa adanya jaminan berupa upah atau pembayaran dalam bentuk lainnya. Adapun keuntungan adanya gotong-royong dalam

20 R. Bintarto, Gotong-Royong : Suatu Karakteristik Bangsa Indonesia (Surabaya : PT. Bina Ilmu, 1980), 24. 
suatu komunitas masyarakat yaitu pekerjaan menjadi mudah dan ringan dibandingkan apabila dilakukan secara perorangan; memerkuat dan memererat hubungan antar warga komunitas di mana mereka berada bahkan dengan kerabatnya yang telah bertempat tinggal di tempat lain, dan menyatukan seluruh warga komunitas yang terlibat di dalamnya.

\section{KESIMPULAN}

Pendidikan perdamaian Kristen dalam konteks Indonesia, sangatlah dibutuhkan dalam kurikulum pendidikan Kristen untuk menanamkan kepada setiap peserta didik mengenai pentingnya memilki relasi yang baik dengan Tuhan dan sesama. Seperti yang Tuhan Yesus ajarkan di dalam Matius 22:37-40 mengenai hukum kasih, bahwa semua orang harus mengasihi Allah dengan segenap hati dan jiwa dan dengan segenap akal budi, serta mengasihi sesama orang lain seperti dirinya sendiri.

Hasil dari pengajaran Yesus mampu memberikan perubahan dalam kehidupan orang-orang pada zaman-Nya. Tuhan Yesus mewujudkan kasih persaudaran yang sesungguhnya, penghargaan terhadap pribadi seseorang, membaharui jiwa, memerbaiki kehidupan rumah tangga, dan lain sebagainya. Hasil pengajaran Tuhan Yesus tidak sampai begitu saja, namun tetap berlanjut bahkan sampai saat ini. Tuhan Yesus sebagai Pendidik tidak hanya mengubah kehidupan para murid-Nya tetapi juga mampu membuat murid-murid-Nya melanjutkan apa yang telah diajarkan-Nya.

Pendidikan Kristen berarti harus mengajarkan mengenai ajaran yang sudah Tuhan Yesus ajarkan, yaitu tentang mengasihi Tuhan dan sesama. Selain itu para pendidik Kristen juga harus mengarahkan para peserta didiknya menjadi anak-anak yang memiliki karakter yang baik serta bertumbuh iman Kristennya. Dengan begitu, para pendidik Kristen menjadi agen yang Tuhan pakai untuk membentuk para peserta didik memiliki hubungan yang baik dengan Tuhan dan sesama. Ketika hal itu terjadi maka mereka akan menjadi pembawa damai bagi orang-orang yang ada di sekitar mereka, sehingga konflik tidak akan muncul karena mereka sudah mengerti akan pentingnya menjaga perdamaian sebagai anak-anak Allah. Seperti yang Tuhan 
Yesus katakan bahwa "berbahagialah orang-orang yang membawa damai, karena mereka akan disebut anak-anak Allah" (Matius 5:9).

Pendidikan Kristen bisa dikatakan berhasil, apabila bisa membawa peserta didik kepada perubahan karakter yang buruk menjadi karakter Kristus, serta memiliki pola pikir yang benar dan membawa mereka kepada pengenalan serta perjumpaan dengan Kristus secara pribadi.

ROBI PRIANTO, adalah dosen tetap di STT SAPPI yang menyelesaikan program Stratum Satu (S.Th.) dari STT SAPPI Cianjur, dan saat ini sedang menyelesaikan program Pascasarjana (S2) dari STT Cipanas. 